\title{
Relative Insensitivity to Glucagon of Sterol Synthesis in Cultured Rat Aortic Smooth Muscle Cells
}

\author{
Effect of Dibutyryl Cyclic AMP
}

\author{
R. W. Stout \\ Department of Geriatric Medicine, The Queen's University of Belfast, Belfast, Northern Ireland
}

Summary. The smooth muscle cell plays an important role in the process of atherogenesis. In these experiments the effect of glucagon and dibutyryl cyclic AMP on sterol synthesis in cultured rat arterial smooth muscle cells was studied. Glucagon in concentrations of $1 \times 10^{-9} \mathrm{~mol} / \mathrm{l}$ inhibited the incorporation of sodium $\left(2-{ }^{14} \mathrm{C}\right)$ acetate into non-saponifiable lipids and digitonin precipitable sterols but lower concentrations of glucagon had no effect. In cells which were exposed to serum, dibutyryl cyclic AMP also resulted in a decrease in the incorporation of labelled acetate into sterols but when the cells were grown in serum free medium, dibutyryl cyclic AMP had no inhibitory effect on sterol synthesis. These results provide further evidence that sterol metabolism in arterial smooth cells may be influenced by hormones but suggest that glucagon is relatively less important than insulin in this respect.

Key words: Glucagon, sterol, smooth muscle cells, aorta, cell culture, cyclic AMP.

The arterial smooth muscle cell has an important role in the development of atherosclerosis [1]. Early in the disease, proliferation of smooth muscle cells is found in the arterial intima and as the lesion develops these cells accumulate lipid, including cholesterol. Evidence has been presented that cholesterol synthesis in the arterial wall is influenced by insulin $[2,3]$ and it has been suggested that abnormal concentrations of circulating insulin may have a role in atherogenesis $[4,5]$. This may be relevant to the development of atherosclerosis in diabetics [5].

As well as abnormal insulin levels diabetics also have abnormalities in glucagon secretion [6]. Gluca- gon has effects on fat metabolism which are generally opposite to those of insulin [7]. Cyclic adenosine $3^{\prime} 5^{\prime}$ monophosphate (cyclic AMP) is closely involved in hormone action [8] and has been identified in the arterial wall [9]. Glucagon activity and cyclic AMP actions are closely related in many tissues [7]. In the present experiments, the influence of glucagon and the dibutyryl analogue of cyclic AMP on sterol metabolism was studied in cultured rat aortic smooth muscle cells.

\section{Materials and Methods}

The culture methods and materials have been described in detail elsewhere $[10,11,3]$. Briefly, small pieces of intima-media were dissected under sterile conditions from the inner surface of the aortas of young male Wistar rats and were incubated in DulbeccoVogt's culture medium at $37^{\circ} \mathrm{C}$. Smooth muscle cells grew out in 10-14 days, and, when confluent, the cells were passed by trypsinisation. As a control, pieces of adventitia were also cultured from the same aortas [12]. Smooth muscle cells were distinguished from adventitial fibroblasts by their long lag period of growth, their slow rate of growth, their tendency to grow in "hills and hollows", their resistance to trypsinisation [13] and their morphology [3]. The cells were studied when they had been passed 6-11 times, corresponding to approximately $12-20$ population doublings.

For the experiments, cells from one flask were passed into 12 $35 \mathrm{~mm}$ Falcon plastic Petri dishes. They were grown to confluency in the dishes in $2 \mathrm{ml}$ culture medium containing $10 \%(\mathrm{v} / \mathrm{v})$ fetal calf serum. The medium was then changed to a medium containing $10 \%$ fetal calf serum, $10 \%(\mathrm{v} / \mathrm{v})$ lipid free serum or $10 \%$ of a $4 \mathrm{~g} /$ $100 \mathrm{ml}$ albumin solution. In each experiment glucagon or dibutyryl cyclic AMP was added to six plates while the same volume of albumin solution was added to the other six which acted as controls. After $24 \mathrm{~h}$ exposure to this medium $1 \mu \mathrm{Ci}$ sodium (2$\left.{ }^{14} \mathrm{C}\right)$ acetate $(59 \mathrm{mCi} / \mathrm{mmol})$ in $25 \mu \mathrm{l}$ distilled water was added to each dish. The dishes were then incubated for a further $2 \mathrm{~h}$. The medium was removed and the cells were washed twice with phosphate buffered saline. The cells were removed from the dishes by trypsinisation and washed twice with $0.15 \mathrm{~mol} / \mathrm{l}$ sodium chloride. The lipids were extracted, the non-saponifiable lipids and digi- 
Table 1. Effect of glucagon on acetate incorporation into sterols in cultured rat aortic smooth muscle cells (experimental details in text)

\begin{tabular}{|c|c|c|c|c|c|c|}
\hline \multirow[b]{2}{*}{ Donor } & \multirow[b]{2}{*}{$\begin{array}{l}\text { Glucagon } \\
(\mathrm{mol} / 1)\end{array}$} & \multicolumn{2}{|l|}{ Non-saponifiable lipids } & \multicolumn{3}{|c|}{ Digitonin precipitable sterols } \\
\hline & & $\begin{array}{l}\text { Control } \\
\text { (dpm/mg cell protein) }\end{array}$ & Glucagon & Control & Glucagon & \\
\hline A & $0.2 \times 10^{-9}$ & $11452 \pm 688$ & $11220 \pm 1016 \quad(98 \%)$ & $1068 \pm 72$ & $1182 \pm 78$ & $(110 \%)$ \\
\hline A & $0.2 \times 10^{-9}$ & $15412 \pm 1044$ & $17568 \pm 3508(115 \%)$ & $2112 \pm 252$ & $1818 \pm 210$ & $(87 \%)$ \\
\hline A & $1 \times 10^{-9}$ & $11776 \pm 328$ & $2780 \pm 352 \quad(23 \%)^{\mathrm{c}}$ & $3060 \pm 258$ & $1440 \pm 108$ & $(47 \%)^{\mathrm{c}}$ \\
\hline A & $1 \times 10^{-9}$ & $16992 \pm 3048$ & $8380 \pm 1660 \quad(49 \%)^{a}$ & $3147 \pm 468$ & $1152 \pm 258$ & $(36 \%)^{b}$ \\
\hline B & $1 \times 10^{-9}$ & $8956 \pm 664$ & $4260 \pm 300 \quad(48 \%)^{c}$ & $1986 \pm 162$ & $924 \pm 78$ & $(47 \%)^{c}$ \\
\hline
\end{tabular}

In each case the results are the mean of six replicate plates \pm SEM

The figures in parenthesis are the values in the cells exposed to glucagon expressed as a percentage of the control values $\mathrm{a}=\mathrm{p}<0.025 ; \mathrm{b}=\mathrm{p}<0.005 ;^{\mathrm{c}}=\mathrm{p}<0.0005$

Table 2. Effect of dibutyryl cyclic AMP on acetate incorporation into sterols in cultured rat aortic smooth muscle cells (experimental details in the text). (Lipid results calculated as $\mathrm{dpm} / \mathrm{mg}$ cell protein and then expressed as a percentage of control values)

\begin{tabular}{llcl}
\hline Medium & $\begin{array}{l}\text { Dibutyryl } \\
\text { cyclic AMP } \\
\text { mol/ } / 1\end{array}$ & $\begin{array}{l}\text { NSL } \\
\%\end{array}$ & $\begin{array}{l}\text { DPS } \\
\%\end{array}$ \\
\hline $10 \%$ FCS & $5 \times 10^{-4}$ & $76^{\mathrm{c}}$ & $67^{\mathrm{c}}$ \\
$10 \%$ FCS & $2 \times 10^{-4}$ & $55^{\mathrm{b}}$ & $69^{\mathrm{a}}$ \\
$10 \%$ LFS & $5 \times 10^{-4}$ & $63^{\mathrm{d}}$ & $72^{\mathrm{a}}$ \\
$10 \%$ LFS & $1 \times 10^{-4}$ & $62^{\mathrm{d}}$ & $65^{\mathrm{a}}$ \\
$10 \%$ albumin & $5 \times 10^{-4}$ & $127^{\mathrm{a}}$ & 99 \\
\hline
\end{tabular}

In each case the results are the mean of six replicate plates $\mathrm{FCS}=$ fetal calf serum; LFS = lipid free serum; NSL $=$ nonsaponifiable lipids; DPS $=$ digitonin precipitable sterols $\mathrm{a}=\mathrm{p}<0.025 ;^{\mathrm{b}}=\mathrm{p}<0.005 ;^{\mathrm{c}}=\mathrm{p}<0.0025 ;^{\mathrm{d}}=\mathrm{p}<0.0005$

tonin precipitable sterols isolated, the radioactivity counted and the cell protein measured as previously described [3].

Lipid free serum was made by extracting fetal calf serum with acetone and ethanol [14]; after extraction no cholesterol could be detected in the serum. Glucagon was obtained from Eli Lilly Ltd; $1 \mathrm{mg}$ was dissolved in $1 \mathrm{ml}$ of the diluting solution supplied $(1.6 \%$ $\mathrm{v} / \mathrm{v}$ glycerin and $0.2 \% \mathrm{v} / \mathrm{v}$ phenol) and diluted to $50 \mathrm{ml}$ with the $4 \mathrm{~g} / 100 \mathrm{ml}$ albumin solution. The concentration of glucagon was measured by radioimmunoassay in medium taken from two groups of six replicate dishes in which the cells were exposed to the two concentrations of glucagon for twenty-six hours. The assay, described in detail elsewhere [15] employs two antisera; the results for the antiserum reacting with the N-terminal region of the glucagon molecule are reported here. Dibutyryl cyclic AMP was obtained from Sigma, London, and dissolved in a sterile bovine serum albumin solution $(4 \mathrm{~g} / 100 \mathrm{ml})$ at a concentration of $10^{-3} \mathrm{~mol} / 1$. The other materials were as previously described [3].

The incorporation of labelled acetate was calculated as disintegrations $/ \mathrm{min} / \mathrm{mg}$ cell protein. The effects of glucagon on dibutyryl cyclic AMP were compared with control experiments in which the cells were not exposed to glucagon or dibutyryl cyclic AMP and which were called $100 \%$. The control and test results were compared by Student's t-test.

\section{Results}

Preliminary experiments showed that the uptake of sodium $\left(2-{ }^{14} \mathrm{C}\right)$ acetate into the non-saponifiable lipids of cultured smooth muscle cells was linear for up to a $24 \mathrm{~h}$ period of incubation. Twenty-six hours after the glucagon was added to the medium, the concentration in the six dishes whose initial concentrations of $0.8 \mathrm{ng} / \mathrm{ml}$ was $0.183 \pm 0.012 \mathrm{ng} / \mathrm{ml}$ (mean \pm SEM) and in the dishes whose initial concentration was $4 \mathrm{ng} / \mathrm{ml}$ it was $1.400 \pm 0.045 \mathrm{ng} / \mathrm{ml}$.

Exposure of the cells to a concentration of glucagon of $4 \mathrm{ng} / \mathrm{ml}$ of culture medium $\left(1 \times 10^{-9} \mathrm{~mol} / \mathrm{l}\right)$ containing $10 \%$ fetal calf serum significantly depressed the incorporation of acetate into sterols to between $23 \%$ and $49 \%$ of control values (Table 1 ). These results were reproducible in replicate experiments in cells from the same donor and also in cells from two different donors. However, glucagon at one-fifth the concentration $(0.8 \mathrm{ng} / \mathrm{ml}$ or $0.2 \times$ $10^{-9} \mathrm{~mol} / \mathrm{l}$ ) had no detectable effect on sterol synthesis. When the diluting solution alone was added to the cells, no effect on sterol synthesis was found.

Exposure of cells to dibutyryl cyclic AMP resulted in depression of incorporation of labelled acetate into both total non-saponifiable lipids and digitonin precipitable sterols (chiefly cholesterol) by up to $45 \%$ (Table 2). This effect was seen when the cells were grown in both normal fetal calf serum and in lipid free serum. However, when the cells were grown in serum free medium no inhibiting effect of dibutyryl cyclic AMP could be detected. The results were replicable in experiments on cells from two different donors.

\section{Discussion and Conclusions}

The results of these experiments show that very high concentrations of glucagon are required to suppress 
incorporation of acetate into sterols in cultured arterial smooth muscle cells. The concentrations of glucagon used are far in excess of physiological or pathological circulating glucagon levels and also higher than those that induce lipolysis in adipose tissue in vitro [7]. Although the concentrations of glucagon in the media decreased considerably during the $26 \mathrm{~h}$ incubation period, they remained much higher than physiological levels measured in the same laboratory [15]. These results are in contrast to the results of the previously reported studies of the effect of insulin on cultured arterial smooth muscle cells where insulin in concentrations within the physiological range stimulated both cell proliferation [11] and sterol synthesis [3].

Abnormal glucagon secretion has been found in diabetes and it has been suggested that glucagon may have a role in some of the metabolic abnormalities of diabetes [16]. In particular, glucagon enhances lipolysis and may be involved in the production of ketone bodies [16]. Recent studies, however, suggest that glucagon's role in diabetes may be minor [17] and its effect on lipolysis in man may be related to low insulin concentrations. It has also been suggested that glucagon deficiency may have a role in both hypercholesterolaemia [18] and hypertriglyceridaemia [19]. These results suggest that insulin may be relatively more important than glucagon in the control of arterial sterol metabolism. Thus, in situations where insulin and glucagon levels may both be elevated, for example in obese diabetics or diabetics receiving large doses of insulin [6] the stimulating effect of insulin on sterol metabolism might overcome the inhibiting effect of glucagon.

The results of these experiments show that dibutyryl cyclic AMP inhibits sterol synthesis in cultured arterial smooth muscle cells. This effect is similar to the action of glucagon and lipoproteins [20] and opposite to the action of insulin [3]. The results are consistent with some of these factors exerting their effects on arterial sterol metabolism by way of changes in intracellular cyclic AMP. In contrast to the results of the glucagon experiments, inhibition of sterol synthesis was achieved with quite small concentrations of dibutyryl cyclic AMP. The effect was only seen in cells exposed to serum. Exposure of cultured smooth muscle cells to serum enhances cholesterol synthesis and lipid free serum causes a further increase in cholesterol synthesis [20]. Thus, it appears that dibutyryl cyclic AMP only inhibits sterol synthesis when the process is active. It has been shown that cyclic AMP inhibits sterol metabolism in the liver $[21,22]$ and that the nucleotide influences the activity of 3-hydroxy-3-methylglutaryl coenzyme A reductase, the rate limiting enzyme in cholesterol synthesis. Thus, while dibutyryl cyclic AMP may not precisely mimic the actions of cyclic AMP, the present experiments provide further evidence that sterol metabolism in arterial smooth muscle cells is influenced by hormonal and metabolic factors but suggest that these cells are relatively insensitive to glucagon.

Acknowledgements. This study was supported by a grant from the British Heart Foundation. The technical help of Mrs Nora Copeland, Mrs Kathleen Hanna and Mrs Anne Simpson is gratefully acknowledged. Professor K. D. Buchanan kindly provided facilities for glucagon radioimmunoassay.

\section{References}

1. Ross, R., Glomset, J. A.: Atherosclerosis and the arterial smooth muscle cell. Science 180, 1332-1339 (1973)

2. Stout, R. W.: Insulin stimulation of cholesterol synthesis by arterial tissue. Lancet 1969 II, 467-468

3. Stout, R. W.: The effect of insulin and glucose on sterol synthesis in cultured rat arterial smooth muscle cells. Atherosclerosis 27, 271-278 (1977)

4. Stout, R. W., Vallance-Owen, J.: Insulin and atheroma. Lancet 1969 I, $1078-1080$

5. Stout, R. W.: The relationship of abnormal circulating insulin levels to atherosclerosis. Atherosclerosis 27, 1-13 (1977)

6. Buchanan, K. D.: Glucagon. In: J. S. Bajaj (Ed.): Insulin and Metabolism, pp 233-270. Amsterdam: Excerpta Medica 1977

7. Lefebvre, P.: Glucagon and adipose tissue. Biochem. Pharmacol. 24, 1261-1266 (1975)

8. Sutherland, E. W., Robison, G. A.: The role of cyclic AMP in the control of carbohydrate metabolism. Diabetes 18, $797-819$ (1969)

9. Gilbert, C. H., Galton, D. J.: The presence of a hormone-sensitive cyclase system in the rat aorta and its relation to lipolysis. Atherosclerosis 18, 257-264 (1973)

10. Ross, R.: The smooth muscle cell, II. Growth of smooth muscle in culture and formation of elastic fibres. J. Cell Biol. 50, 172-186 (1971)

11. Stout, R. W., Bierman, E. L., Ross, R.: The effect of insulin on the proliferation of cultured primate arterial smooth muscle cells. Circ. Res. 36, 319-327 (1975)

12. Bierman, E. L., Stein, O., Stein, Y.: Lipoprotein uptake and metabolism by rat aortic smooth muscle cells in tissue culture. Circ. Res. 35, 136-150 (1974)

13. Gimbrone Jr, M. A., Cotran, R. S., Folkman, J.: Human vascular endothelial cells in culture. J. Cell Biol. 60, 673--684 (1974)

14. Rothblat, G. H., Arbogast, L. Y., Ouellette, L., Howard, B. V.: Preparation of delipidized serum protein for use in cell culture systems. In Vitro 12, 554-557 (1976)

15. Stout, R.W., Henry, R. W., Buchanan, K. D.: triglyceride metabolism in acute starvation: the role of secretin and glucagon. Eur. J. Clin. Invest. 6, 179-185 (1976)

16. Gerich, J. E., Lorenzi, M., Bier, D.M., Schnieder, V., Tsalikian, E., Karam, J. M., Forsham, P. H.: Prevention of human diabetic ketoacidosis by somatostatin. Evidence for an essential role of glucagon. N. Engl. J. Med. 292, 985-989 (1975)

17. Barnes, A. J., Bloom, A., Crowley, M. F., Tuttlebee, J. W., Bloom, S. R., Alberti, K. G. M. M., Smythe, P., Turnell, D.: Is glucagon important in stable insulin-dependent diabetics? Lancet 1975 II, 734-737 
18. Friedman, M., Byers, S. O., Rosenman, R. H., Elek, S.: Effect of glucagon on blood-cholesterol levels in rats. Lancet 1971 II, 464-466

19. Eaton, R. P., Schade, D. S., Conway, M.: Decreased glucagon activity: a mechanism for genetic and acquired endogenous hyperlipaemia. Lancet 1974 II, 1545-1547

20. Stout, R. W.: The effect of serum, lipid free serum and high density lipoprotein on sterol synthesis in cultured arterial smooth muscle cells (abstract). Clin. Sci. Mol. Med. 52, 19 (1977)

21. Bricker, L. A., Levey, G. S.: Evidence for regulation of cholesterol and fatty acid synthesis in liver by cyclic adenosine $3^{\prime}, 5^{\prime}-$ monophosphate. J. Biol. Chem. 247, 4914-4915 (1972)
22. Beg, Z. H., Allmann, D. W., Gibson, D. M.: Modulation of 3hydroxy-3-methylglutaryl coenzyme A reductase activity with cAMP and with protein fractions of rat liver cytosol. Biochem. Biophys. Res. Commun. 54, 1362-1369 (1973)

Received: January 16, 1978, and in revised form: May 8, 1978

Prof. R. W. Stout

The Queen's University of Belfast

Department of Geriatric Medicine

Whitla Medical Building

97 Lisburn Road

Belfast BT9 7BL, Northern Ireland 